\title{
PERBEDAAN REGULASI DIRI BELAJAR PADA SISWA SEKOLAH DASAR KELAS VI DITINJAU DARI JENIS KELAMIN
}

\author{
Ruminta $^{1}$, Sri Tiatri ${ }^{2}$, Heni Mularsih ${ }^{3}$ \\ ${ }^{1}$ Fakultas Psikologi Universitas Tarumanagara \\ Email: lusiaksfl@gmail.com \\ ${ }^{2}$ Fakultas Psikologi Universitas Tarumanagara \\ Email: sri.tiatri@untar.ac.id \\ ${ }^{3}$ Fakultas Psikologi Universitas Tarumanagara \\ Email: henim@mku.untar.ac.id
}

\begin{abstract}
ABSTRAK
Keberhasilan seorang dalam menjalani proses pendidikannya dipengaruhi oleh beberapa faktor, antara lain selfregulation (regulasi diri belajar). Regulasi diri belajar adalah kemampuan untuk memunculkan dan memonitor sendiri baik pikiran, perasaan, dan perilaku untuk mencapai tujuan belajar. Regulasi diri belajar penting agar siswa memiliki kemandirian dalam belajar. Terdapat perbedaan hasil penelitian mengenai regulasi diri belajar ditinjau dari jenis kelamin. Penelitian ini bertujuan untuk mengkaji lebih lanjut, apakah terdapat perbedaan regulasi diri belajar pada siswa Sekolah Dasar kelas VI ditinjau dari jenis kelamin. Subyek penelitian adalah 188 siswa kelas VI pada salah satu sekolah swasta di Bekasi. Siswa laki-laki berjumlah 94 dan 91 siswa perempuan. Penelitian ini menggunakan metode penelitian kuantitatif deskriptif. Pengumpulan data menggunakan kuesioner regulasi diri belajar yang telah diadaptasi sebelumnya dari teks aslinya, yaitu Motivated Strategies for Learning Questionnaire, yang dikembangkan oleh Pintrich dan De Groot (1990). Hasil penelitian menunjukkan bahwa tidak ada perbedaan yang signifikan dalam hal regulasi diri belajar antara siswa laki-laki dan perempuan ( $p=0,072,>0,05)$. Pada empat dimensi yang diukur terdapat tingkat regulasi diri belajar yang sama antara siswa laki-laki dan perempuan. Hanya pada dimensi kecemasan terdapat perbedaan $(p=0,003,<$ $0,05)$.
\end{abstract}

Kata kunci: regulasi diri belajar, jenis kelamin, siswa, sekolah dasar

\section{PENDAHULUAN}

Lembaga pendidikan dari tingkat dasar sampai tingkat tinggi berkompetisi untuk menghasilkan lulusan yang berkualitas (Martono, 2017). Salah satu indikator kualitas adalah persentase kelulusan yang tinggi dan diterima di sekolah favorit. Selain sekolah, orang tua pun mengharapkan putera/puteri mereka berhasil dalam belajar (Pintrich \& Schunk, 1996). Orang tua bahkan terkesan memaksa siswa harus berprestasi dan lebih baik dibandingkan dengan siswa lainnya. Alasannya karena siswa menjadi kebanggaan orang tua yang dapat meningkatkan nama baik orang tua di kalangan keluarga dan masyarakat. Secara umum orang tua akan melakukan banyak hal demi keberhasilan siswa. Mempersiapkan apa saja yang menjadi kebutuhan sekolah dan tidak jarang orang tua bahkan terkesan mengambil alih tanggung jawab siswa dalam menyelesaikan tugas-tugas sekolah (Slameto, 1991). Di saat ujian pun orang tua yang lebih repot mempersiapkan diri bukan siswa. Semua diurus orang tua bahkan foto copy bahanbahan yang dibutuhkan. Dalam perbincangan dengan peneliti, seorang kepala sekolah SD di Bekasi, menyatakan, "Sekarang ini orang tua yang repot, siswanya dibiarkan santai dan orang tua yang sibuk mencari bahan-bahan, pinjam buku temannya dan fotocopy". Hal ini menjadi penyebab siswa kurang mandiri, kurang bertanggung jawab dan kurang termotivasi untuk melakukan tugas sebagai siswa. Padahal kemandirian siswa adalah penting dalam proses belajar (Zimmerman, 2012).

Siswa yang tidak memiliki tanggung jawab, kemandirian dan motivasi dalam belajar berarti belum memiliki self-regulation. Self-regulation menurut Zimmerman (2012), bukanlah suatu kemampuan dalam akademik, namun lebih kepada cara mengatur proses belajar individu secara mandiri melalui perencanaan, pengaturan dan pencapaian tujuan. Setiap individu juga diharapkan 
mampu menemukan strategi belajar yang tepat untuk mempermudah proses belajar. Terdapat tiga aspek regulasi diri belajar yaitu: pertama metakognisi, pada aspek ini siswa mulai merencanakan, menetapkan tujuan, dan mengevaluasi tugas. Kedua aspek motivasi, yaitu ketika individu memiliki keyakinan dan semangat yang tinggi dalam mengerjakan suatu tugas (Boekaerts, Pintrich, \& Zeidner, 2000). Ketiga, aspek perilaku, lebih kepada upaya individu untuk memilih, menstruktur, dan menciptakan lingkungan yang mengoptimalkan belajar.

Siswa laki-laki dan perempuan yang memiliki tingkat regulasi diri belajar tinggi, mampu meprioritaskan belajar dan mengerjakan tugas. Mereka aktif dalam organisasi tanpa tertinggal dalam pembelajaran di kelas (Zimmerman, 2012). Mereka berani dan mau bertanya kepada teman maupun guru dalam menyelesaikan tugas. Sebaliknya siswa dengan tingkat regulasi diri belajar rendah cenderung kurang memiliki rencana. Usaha yang kurang dalam mengikuti proses pembelajaran. Siswa mudah menyerah apabila tidak mampu mengerjakan tugas. Kesulitan dalam belajar, pasif dalam kelas dan tidak mampu mencapai hasil maksimal. Dampak yang ditimbulkan adalah prestasi belajar yang rendah dan mungkin juga tinggal kelas (Lien, Tilor \& Seeman, 2002).

Faktor yang mempengaruhi regulasi diri belajar adalah jenis kelamin dan tingkatan kelas (Zimmerman, 1989). Beberapa hasil penelitian tentang regulasi diri belajar menunjukkan adanya ketidak konsistenan hasil penelitian antara siswa laki-laki dan perempuan pada daerah atau tempat berbeda. Lien, Tilor dan Seeman (2002) di California menunjukkan bahwa perempuan memiliki regulasi diri belajar lebih baik dari laki-laki. Berbeda dengan Jenny (2001) yang menyatakan bahwa di Israel dan Singapura laki-laki lebih baik regulasi diri belajarnya dibanding perempuan.

Kajian penelitian di Indonesia seperti yang dilakukan oleh Ahmad (2010) pada pelajar SMP Bekasi. Hasil penelitiannya menyatakan bahwa tidak ada perbedaan regulasi diri belajar antara siswa laki-laki dan perempuan. Berbeda dengan hasil penelitian yang dilakukan oleh Ayu Permata Sari dan kawan-kawan (2015) pada pelajar SMAN 1 Batusangkar Minangkabau dan di SMAN 1 Balige. Hasil penelitian mereka menunjukkan bahwa terdapat perbedaan regulasi diri belajar pada siswa laki-laki dan perempuan. Perempuan memiliki regulasi diri belajar lebih tinggi dibanding laki-laki.

Hasil wawancara dengan kepala sekolah K (8 September 2017), berkurang atau tidak adanya sikap mandiri, disiplin dan tanggung jawab pada siswa ini menjadi keprihatinan kepala sekolah, guru dan pemerhati pendidikan. Banyak siswa yang sangat tergantung pada orangtua dan guru sehingga pengetahuan siswa tidak bertambah, karena tidak mampu mengatur diri.

Temuan yang berbeda dari beberapa penelitian tersebut, dan perbincangan dengan kepala Sekolah pada salah satu sekolah swasta di Bekasi mendorong peneliti untuk melakukan penelitian tentang regulasi diri belajar pada siswa Sekolah Dasar kelas VI. Peneliti memilih kelas VI dengan asumsi bahwa mereka sudah dapat mengevaluasi dirinya setelah kurang lebih 6 tahun menjalani proses belajar. Memilih sekolah dasar juga berkaitan dengan penelitian sebelumnya yang berfokus pada siswa SMP, SMA dan mahasiswa. Siswa kelas VI secara tidak langsung sudah dituntun memiliki kemandirian dalam belajar sehingga lebih siap memasuki sekolah lanjutan (SMP) yang memiliki tanggung jawab belajar lebih besar. Alasan lainnya adalah beberapa penelitian yang sudah dilakukan ada pada level siswa SMP dan SMA atau SMK. Tujuan peneliti ini untuk mengetahui apakah ada perbedaan regulasi diri belajar pada siswa/i SD ditinjau dari jenis kelamin. 
Istilah self-regulation, Susanto (2006) menyebutkan, siswa yang memiliki tingkat inteligensi, kepribadian, lingkungan rumah dan sekolah yang baik, perlu didukung dengan kemampuan selfregulation untuk mencapai keberhasilan belajar yang diharapakan. Self-regulation adalah kemampuan untuk mengembangkan kontrol atas pikiran, perasaan, kognisi, motivasi dan tindakan dalam lingkungan eksternal seseorang (Bandura, 1986). Istilah self-regulation yang digunakan dalam belajar dikenal sebagai regulasi diri belajar. Salah satu teori yang menjelaskan tentang regulasi diri belajara adalah teori sosial kognitif. Menurut teori sosial kognitif, regulasi diri belajar tidak hanya ditentukan oleh proses pribadi, tetapi juga dipengaruhi oleh lingkungan dan perilaku secara timbal balik (Zimmerman, 2012).

Regulasi Diri Belajar mencakup tiga aspek yang diaplikasikan dalam belajar, yaitu metakognitif, motivasi, dan perilaku yang dipaparkan sebagai berikut. Pertama, metakognisi. Metakognisi adalah pemahaman dan kesadaran tentang proses kognitif atau pikiran tentang berpikir (Matlin, 1993). Metakognisi ini meliputi perencanaan, pemonitoran (pemantauan), dan perbaikan dari performansi atau perilakuya. Zimmerman (2012) menambahkan bahwa poin metakognitif dalam regulasi diri belajar adalah proses memahami pendekatan pembelajaran dalam proses berfikir dengan merencanakan, menetapkan tujuan, memonitor, mengorganisasikan dan mengevaluasi kegiatan belajar. Aspek Regulasi Diri Belajar yang kedua adalah motivasi. Deci dan Ryan (1985) mengemukakan bahwa motivasi adalah fungsi dari kebutuhan dasar untuk mengontrol dan berkaitan dengan kemampuan yang ada pada setiap diri individu. Ditambahkan pula oleh Zimmerman (2012) bahwa keuntungan motivasi ini adalah individu memiliki ketertarikan terhadap tugas yang diberikan dan berusaha dengan tekun dalam belajar dengan memilih, menyusun, dan menciptakan lingkungan yang disukai untuk belajar. Aspek regulasi diri belajar yang ketiga adalah perilaku. Menurut Zimmerman dan Schunk (1998) perilaku merupakan upaya individu untuk mengatur diri, menyeleksi, dan memanfaatkan maupun menciptakan lingkungan yang mendukung aktivitasnya. Pada aspek perilaku ini, Zimmerman (2012) mengatakan bahwa individu memilih, menyusun, dan menciptakan lingkungan sosial dan fisik seimbang untuk mengoptimalkan pencapaian atas aktivitas yang dilakukan.

Ada sejumlah faktor yang dapat mendukung regulasi diri belajar. Faktor-faktor tersebut adalah pertama, keyakinan mengenai kemampuan diri (self efficacy). Menurut Pintrich dan kawankawan (2003), self efficacy adalah sejumlah komponen pada individu atau keyakinan akan kemampuan individu dalam belajar dan memperlihatkan kemampuan tersebut pada tingkat tertentu. Faktor kedua adalah nilai-nilai intrinsik (intrinsic values). Pintich dan kawan-kawan (2003) mengatakan bahwa nilai-nilai intrinsik ini merupakan keyakinan pada manfaat atau pentingnya suatu tugas sehingga memunculkan ketertarikan pada tugas dimaksud. Regulasi diri belajar bergantung pada masing-masing pribadi yang meliputi pengetahuan, proses metakognitif, tujuan, dan afeksi.

Regulasi diri belajar menggabungkan banyak hal tentang belajar efektif seperti pengetahuan, motivasi, dan perilaku disiplin diri. Siswa yang belajar dengan regulasi diri dengan baik dapat mengenal dirinya sendiri dan bagaimana cara mereka belajar. Regulasi diri belajar memiliki pengaruh yang sangat penting dalam dunia pendidikan (Zimmerman, 2012). Proses pembelajaran bagi siswa diharapkan tidak hanya kegiatan belajar mengajar ketika sekolah, namun di rumah dan aktif mengikuti kegiatan yang dapat menambah wawasan. 
Regulasi diri belajar sangat penting untuk memungkinkan keberhasilan di kalangan siswa sejak usia dini melalui semua tahapan pembelajaran (Masrun, 2000). Regulasi diri belajar merupakan salah satu teori belajar yang konstruktifis yang memampukan siswa mencapai tujuan belajar. Seorang siswa harus memiliki kemampuan mengatur dirinya sendiri. Apabila seorang siswa dihadapkan pada permasalahan-permasalahan yang kompleks maka dia akan mengetahui bagaimana memecahkan masalah tersebut (Zimmerman, 2012).

Ada sejumlah faktor yang dapat mendukung regulasi diri belajar. Faktor-faktor tersebut adalah: (a) Keyakinan mengenai kemampuan diri (self efficacy). Menurut Pintrich dan kawan-kawan (1991), self efficacy adalah sejumlah komponen pada individu atau keyakinan akan kemampuan individu dalam belajar dan memperlihatkan kemampuan tersebut pada tingkat tertentu. Self efficacy berkaitan dengan keyakinan akan kemampuan melakukan tugas disertai dengan tanggung jawab atas hasil yang diperoleh. Faktor kedua yang dapat mendukung regulasi diri belajar adalah: (b) Nilai-nilai Intrinsik (Intrinsic values). Pintrich dan kawan-kawan (1991) mengatakan bahwa nilai-nilai intrinsik ini merupakan keyakinan pada manfaat atau pentingnya suatu tugas sehingga memunculkan ketertarikan pada tugas dimaksud.

Thoresen dan Mahoney (dalam Zimmerman, 2012) memaparkan perspektif sosial-kognitif, bahwa keberadaan regulasi diri belajar ditentukan oleh tiga faktor yaitu person, perilaku, dan lingkungan, yang diuraikan sebagai berikut: (a) Faktor pribadi (person). Regulasi diri belajar bergantung pada masing-masing pribadi yang meliputi pengetahuan, proses metakognitif, tujuan, dan afeksi. Pengertian pengetahuan dalam regulasi diri belajar artinya seseorang harus memiliki kemampuan dalam menggunakan strategi tersebut secara efektif, pengetahuan tersebut harus didukung dengan proses metakognitif yang baik. Proses metakognitif di sini berfungsi untuk perencanaan siswa dan menganalisisis tujuan (goals) dalam belajar. Tujuan dan pemakaian proses metakognitif dipengaruhi oleh persepsi terhadap self-efficacy dan afeksi (affect).

Faktor penentu keberadaan regulasi diri belajar yang kedua adalah, (b) Faktor perilaku (Behavior). Ada tiga cara untuk melihat perilaku dalam regulasi diri belajaryaitu observasi diri, penilaian diri dan reaksi. Ketiganya memiliki hubungan yang sifatnya timbal balik seiring dengan konteks persoalan yang dihadapi. Faktor ketiga, adalah (c) Faktor lingkungan. Upaya yang dilakukan dalam menciptakan lingkungan tersebut dapat dengan cara mencari bantuan sosial dari orang lain, mengatur tempat belajar dan mencari ilmu dari berbagai sumber.

Uraian di atas hendak mengatakan bahwa regulasi diri belajar tidak berdiri sendiri. Hal ini berarti untuk mencapai regulasi diri belajar tinggi seorang siswa hendaknya mampu melihat dan memiliki semua faktor yang mendukung. Adalah penting memiliki keyakinan akan kemampuan, motivasi dan menciptakan lingkungan belajar untuk mendukung proses belajar sehingga mencapai prestasi yang diharapkan.

Tiga aspek yang harus dipenuhi yaitu metakognitif, motivasi dan perilaku atau interaksi aktif individu. Metakognitif berhubungan dengan perencanaan proses berfikir seseorang dalam pembelajaran. Siswa harus mampu menilai kemampuan dirinya untuk dapat melakukan tugas sehingga ia dapat menentukan strategi pembelajaran dan proses berfikir yang tepat untuk mencapai tujuan yang telah ditetapkan. Selain itu kesuksesan pembelajaran siswa tidak hanya ditentukan dari satu aspek saja misalnya keberhasilan metakognisi saja, tetapi juga dipengaruhi oleh motivasi dan interaksi aktifnya. Siswa yang memiliki motivasi tinggi akan memiliki ketertarikan lebih terhadap tugas-tugas yang diberikan sehingga pembelajaran dapat berlangsung dengan suka cita tanpa tekanan dari dalam dirinya. Selain itu mahasiswa yang mampu 
berinteraksi aktif terhadap lingkungan dengan memilih, menyusun dan menciptakan lingkungan belajar yang nyaman dan efektif akan lebih mudah menentukan tujuan yang hendak dicapai (Zimmerman, 2012).

Self-regulated learner adalah individu yang mampu menentukan tujuan dan menggunakan strategi yang tepat untuk mencapai tujuan belajar. Schunk dan Zimmerman (Wolters, 1998) mengemukakan bahwa regulasi diri belajar bukan merupakan kemampuan mental (inteligensi) atau keterampilan akademik seperti kecakapan membaca, tetapi suatu proses pengarahan diri yang melibatkan transformasi dari kemampuan mental menuju keterampilan akademik individu. Ini adalah proses siklus di mana peserta didik menetapkan tujuan mereka, menggunakan strategi yang berbeda untuk mencapai tujuan mereka, dan memonitor dan mengevaluasi kinerja mereka. Secara keseluruhan, regulasi diri belajar mendorong siswa untuk mengambil tanggung jawab belajar dengan menggunakan metakognitif, motivasi, dan tindakan strategis (Zimmerman, 2012).

Siswa yang mempunyai regulasi diri belajar menunjukkan berbagai karakteristik berikut: (1) Mengatur tujuan belajar guna mengembangkan pengetahuan dan meningkatkan motivasi; (2) Menyadari hal-hal yang mempengaruhi kondisi emosional dan mempunyai strategi untuk mengatur emosi agar tidak mengganggu kegiatan belajar; (3) Memantau kemajuan yang mendekati target belajar secara periodik; (4) Memeriksa strategi belajar yang didasarkan pada kemajuan yang dicapai; (5) Mengevaluasi rintangan yang mungkin timbul, dan membuat adaptasi yang diperlukan (Santrock, 2008).

Berdasarkan pendapat beberapa ahli di atas yaitu Bandura, Boekaerts, Masrun, Zimmarmen, Santrock, Weinstein, dan Wolter dapat dikatakan bahwa regulasi diri belajar adalah proses pembelajaran individu yang dilakukan secara mandiri dan terencana. Dimulai dengan menyusun serangkaian aktivitas belajar sesuai dengan tujuan yang sudah ditetapkan sebelumnya. Setelah tujuan tercapai, kemudian dilanjutkan dengan mengevaluasi hasil untuk dapat diperbaiki dan ditingkatkan agar mencapai hasil yang optimal dikemudian hari. Regulasi diri belajar ini harus ditanamkan sejak diri untuk melatih siswa dalam disiplin, tanggung jawab dan kemandirian dalam belajar.

\section{METODE PENELITIAN}

Subyek dalam penelitian ini adalah siswa Sekolah Dasar (SD) kelas VI baik laki-laki dan perempuan. Peneliti memilih kelas VI dengan asumsi bahwa mereka telah mampu mengevaluasi cara belajarnya yang sudah berlangsung selama 6 tahun dan juga untuk melihat kesiapan mereka memasuki sekolah lanjutan (SMP) yang memiliki tanggung jawab belajar lebih besar. Subyek dalam penelitian ini tidak melihat perbedaan umur, ekonomi dan suku. Subyek berada pada sekolah yang sama bertujuan untuk memudahkan proses pengambilan data penelitian.

Subyek dalam penelitian ini berjumlah 188 orang dan semuanya kelas VI. Siswa laki-laki berjumlah 94 dan 91 siswa perempuan. Pengambilan sampel menggunakan tehknik purposive sampling, yaitu subyek penelitian dipilih berdasarkan kriteria yang telah ditentukan.

Penelitian ini menggunakan metode penelitian kuantitatif non-eksperimental yaitu metode kuantitatif deskriptif. Penelitian deskriptif adalah suatu penelitian yang dilakukan dengan tujuan utama untuk memberikan gambaran atau deskripsi tentang suatu keadaan secara objektif (Sukmadinata, 2011). 
Penelitian dilakukan pada satu lokasi yaitu salah satu Sekolah Dasar Swasta di Bekasi. Pengambilan data dilakukan di halaman sekolah dengan alasan dapat menampung 188 siswa dan pengambilan data dapat berlangsung serempak. Instrumen yang digunakan dalam penelitian ini adalah kuesioner regulasi diri belajar yang telah diadaptasi sebelumnya oleh penulis dari teks aslinya yaitu Motivated Strategies for Learning Questionnaire dari Pintrich \& De Groot (1990). Regulasi diri belajar terdiri dari empat dimensi yaitu Self-efficacy, intrinsic value, kecemasan, strategi self-regulated learning. Pengujian validitas instrumen yang telah dilakukan yaitu: (a) validitas permukaan melalui 30 orang subyek, (b) validitas konten oleh 3 pakar Psikologi Pendidikan. Uji reliabilitas alat ukur menggunakan pengujian konsistensi internal Cronbach's Alpha. Berdasarkan uji validitas dan reliabilitas, diperoleh data bawa semua butir dari empat dimensi yaitu self-efficacy, intrinsic value, kecemasan, dan regulasi diri belajar dinyatakan valid dan reliabel. Terdapat dua butir dalam alat ukur yang dibuang, yaitu butir 27 dan 37 dalam dimensi strategi regulasi diri belajar. Alat ukur yang digunakan terdiri atas 48 butir.

\section{HASIL DAN PEMBAHASAN}

Berdasarkan jenis kelamin, jumlah subyek tidak terlalu berbeda. Subyek berjenis kelamin lakilaki berjumlah 94 orang dan perempuan berjumlah 91 orang. Tabel 1 menunjukkan gambaran jumlah subyek penelitian berdasarkan jenis kelamin.

Tabel 1. Gambaran Subyek Berdasarkan Jenis Kelamin

\begin{tabular}{|c|c|c|c|c|c|c|c|c|c|}
\hline & & & & & & & Frekuensi & Persen & Persen Kumulatif \\
\hline & & & & & $\overline{\text { Valid }}$ & laki-laki & 94 & 50,8 & 50,8 \\
\hline & & & & & & perempuan & 91 & 49,2 & 100 \\
\hline & & & & & & Total & 185 & 100,0 & \\
\hline
\end{tabular}

Hasil pengolahan data uji Mann-Whitney menunjukkan bahwa tidak ada perbedaan regulasi diri belajar siswa laki-laki dan perempuan, dilihat dari nilai $p=0,072(0,072>0,05)$. Nilai signifikansi lebih dari $0.05(p>0.05)$, menunjukkan bahwa tidak terdapat perbedaan signifikan antara siswa laki-laki dan perempuan.

Secara rinci, tabel 2 menunjukkan gambaran regulasi diri belajar siswa, dan tabel 3 menunjukkan uji beda regulasi diri belajar. Hasil pengolahan data uji Mann-Whitney menunjukkan tidak ada perbedaan regulasi diri belajar antara siswa laki-laki dan perempuan.

Tabel. 2 Gambaran dan Uji Beda Regulasi Diri Belajar

\begin{tabular}{llllll}
\hline & & & Std. & & \\
& $\mathrm{N}$ & Mean & Deviation & Minimum & Maximum \\
\hline Regulasi Diri Belajar & 184 & 3,50 &, 33 & 1,66 & 4,16 \\
& 185 & 1,49 &, 501 & 1 & 2 \\
\hline
\end{tabular}

\begin{tabular}{lllll} 
& Jenis kelamin & N & Mean Rank & Sum of Ranks \\
\hline Regulasi Diri Belajar & laki-laki & 94 & 85,58 & 8044,50 \\
& perempuan & 90 & 99,73 & 8975,50 \\
& Total & 184 & & \\
\hline
\end{tabular}


Tabel 3. Uji Beda Regulasi Diri Belajar

\begin{tabular}{ll}
\hline & Regulasi Diri Belajar \\
\hline Mann-Whitney U & 3579,500 \\
Wilcoxon W & 8044,500 \\
Z & $-1,801$ \\
Asymp. Sig. (2-tailed) &, 072 \\
\hline
\end{tabular}

a. Grouping Variable: jenis kelamin

Tabel 4 menunjukkan uji beda regulasi diri belajar ditinjau dari 5 dimensi regulasi diri belajar. Kelima dimensi tersebut adalah: dimensi self-efficacy, dimensi motivation value, dimensi kecemasan, dimensi strategi regulated learning, dan dimensi self-regulation.

Tabel 4. Uji Beda Berdasarkan Dimensi Regulasi Diri Belajar

\begin{tabular}{lrrrrr}
\hline & & & \multicolumn{2}{c}{ strategi regulated } \\
& self-efficacy & motivation value & kecemasan & learning & self regulation \\
\hline Mann-Whitney U & 4039,000 & 3978,000 & 3170,500 & 3714,500 & 4224,000 \\
\hline Wilcoxon W & 8225,000 & 8443,000 & 7635,500 & 8179,500 & 8689,000 \\
\hline Z &,- 655 &,- 825 & $-2,947$ & $-1,546$ &,- 146 \\
\hline Asymp. Sig. (2-tailed) &, 512 &, 410 &, 003 &, 122 &, 884 \\
\hline a. Grouping Variable: jenis kelamin & & & & & \\
\hline
\end{tabular}

Hasil pengolahan data uji Mann-Whitney diperoleh bahwa tidak ada perbedaan regulasi diri belajar antara siswa laki-laki dan perempuan dengan nilai $p=0,072(0,072>0,05)$. Dilihat dari kelima dimensi regulasi diri belajar, diperoleh hasil tidak ada perbedaan antara siswa laki-laki dan perempuan kecuali pada dimensi kecemasan. Data sebagai berikut: (1) Dimensi self-efficacy menunjukkan hasil $p=0.731$; (2) Dimensi Intrinsic motivation Value $p=0,243$; (3) Dimensi selfregulation $p=0,719$; (4) Dimensi dan strategi regulation learning $p=0.107$; (5) Dimensi kecemasan terdapat perbedaan antara siswa laki-laki dan perempuan dengan signifikan $p=0,002$.

Hasil temuan ini mendukung penelitian yang dilakukan oleh Ahmad (2010) yang mengatakan tidak ada perbedaan regulasi diri belajar antara siswa laki-laki dan perempuan. Hasil temuan ini menyatakan bahwa baik siswa laki-laki dan perempuan memiliki dan menunjukkan karakteristik regulasi diri belajar yang sama pada keempat dimensi.

Sebagaimana dikatakan Santrock (2007) siswa yang memiliki kemampuan regulasi diri belajar menunjukan karateristik mengatur tujuan belajar. Mengembangkan ilmu dan meningkatkan motivasi. Mengendalikan emosi sehingga tidak mengganggu kegiatan pembelajaran. Memantau secara periodik kemajuan target belajar dan mengevaluasinya. Kemampuan self-regulated 
learning sangat penting dimiliki oleh siswa, agar memiliki disiplin dan tanggung jawab yang besar terhadap diri dan perilaku demi tercapainya tujuan yang telah ditargetkan.

Pada empat dimensi yang diukur, siswa laki-laki dan perempuan memiliki regulasi diri belajar yang sama kecuali dimensi kecemasan. Pada dimensi kecemasan diperoleh perbedaan yang signifikan antara siswa laki-laki dan perempuan. Perempuan memiliki tingkat kecemasan lebih tinggi daripada laki-laki. Hal ini sejalan dengan pernyataan Papalia dkk. (2011). Salah satu kemungkinan penjelasan adalah bahwa pengalaman menarche pada remaja perempuan akan menimbulkan kecemasan, disebabkan tidak adanya persiapan emosional yang matang. Siswa perempuan dalam penelitian ini diasumsikan memasuki usia pubertas dan baru mengalami menarche.

\section{KESIMPULAN DAN SARAN}

Berdasarkan hasil penelitian dan analisis data yang dilakukan, dapat ditarik kesimpulan bahwa tidak terdapat perbedaan tingkat regulasi diri belajar yang signifikan antara siswa laki-laki dan perempuan. Dalam empat dari dimensi regulasi diri belajar pun tidak tampak perbedaan. Perbedaan hanya tampak pada satu dimensi dari regulasi diri belajar, yaitu dimensi kecemasan. Siswa perempuan tampak lebih tinggi daripada laki-laki dalam dimensi kecemasan.

Hasil penelitian ini menjadi tambahan perbendaharaan pengetahuan mengenai regulasi diri belajar ditinjau dari jenis kelamin. Berdasarkan hasil penelitian ini, peneliti menyarankan agar orang tua atau guru dapat memandang regulasi diri belajar laki-laki tidak berbeda dari regulasi diri perempuan. Adanya temuan bahwa perempuan lebih tinggi daripada laki-laki dalam dimensi kecemasan menyebabkan diperlukannya tindak lanjut. Siswa perempuan tampak lebih memerlukan dukungan dari lingkungan sosial, dalam upaya meregulasi dirinya.

\section{Ucapan Terima Kasih}

Terima kasih bagi semua pihak terkait penelitian ini. Terima kasih atas Kepala Sekolah yang telah memberikan izin pengambilan data, serta bersedia diwawancarai. Terima kasih kepada guru kelas yang telah memberikan kesempatan kepada peneliti untuk mengambil data. Terima kasih kepada para siswa yang telah bersedia menjadi subyek dalam penelitian ini. Terima kasih juga kepada Program Studi Magister Psikologi yang melalui kurikulumnya telah memberikan kesempatan bagi penulis untuk melaksanakan penelitian, sebagai bagian dari kelengkapan mata kuliah.

\section{REFERENSI}

Ahmad, R. (2010). Pengelolaan Pembelajaran. Rineka Cipta: Jakarta.

Bandura, A. (1986). Social foundations of thought and action: A social cognitive theory. Englewood Cliffs, N.J.: Prentice-Hall.

Boekaerts, M., Pintrich, P.R., \& Zeidner, M. (Eds.) (2000). Handbook of selfregulation. San Diego, CA: Academic Press.

Deci, E. L., \& Ryan, R. M. 1985. Intrinsic Motivation and Self-Determination in Human Behavior. New York, NY: Springer.

Jenny, K. (2001). Self regulated strategies in achievement settings cullture and gender differences. Universitas of Haifa. Journal of Cross Cultural Phychology, 32 (4), 491-503. 
Lien, B.P., Tilor, E., \& Seeman, T.E. (2002). Effects of environmental predictability and personal mastery on self regulatory and physiological processes. The Society for Personality and Social Psychology. California.

Martono. N. (2017). Sekolah publik vs sekolah privat. Jakarta: Jakarta.

Masrun. (2000). Peran Psikologi di Indonesia. Yogyakarta: Yayasan Pembina Fakultas Psikologi UGM.

Matlin, M. W. ( 1993). Cognition. New York, NY: Holt, Rinehart and Winston.

Papalia, D.E., Old, S.W., \& Feldman, R.D. (2011). Human Development (11 $1^{\text {th }}$ ed.). New York, NY: McGraw-Hills.

Permatasari, A., Nirwana, N., Ahmad, R. (2015). Regulasi diri belajar dan locus of control siswa ditinjau dari jenis kelamin dan latar belakang budaya. Jurnal konselor, 4 (2). Diunduh dari http://ejournal.unp.ac.id/index.php/konselor.

Pintrich, P. R. (2003). A motivational science perspective on the role of student motivation in learning and teaching contexts. Journal of Educational Psychology, 95, 667-686. doi:10.1037/0022-0663.95.4.667.

Pintrich, P. R., \& Schunk, D. H. (1996). Motivation in education: Theory, research, and applications. Englewood Cliffs, NJ: Merrill-Prentice Hall.

Santrock, J W. (2007). Perkembangan Siswa. (Alih Bahasa Mila Rachmawati dan Wibi Handani). Jakarta: Erlangga.

Sarwono, S. (2011). Psikologi remaja. Jakarta: Raja Grafindo Persada.

Slameto (1991). Belajar dan faktor-faktor yang mempengaruhinya. Jakarta: Rineka Cipta.

Sukmadinata. N S. (2013). Metode Penelitian Pendidikan. Bandung: Remaja Rosdakarya

Susanto, H. (2006). Mengembangkan kemampuan self regulation untuk meningkatkan keberhasilan akademik siswa. Jurnal Pendidikan Penabur, 5 (7), 64-71.

Weinstein, C. E., Acee, T. W., \& Jung, J. (2011). Self-regulation and learning strategies: New directions for teaching and learning. Journal of Educational Psychology, 45-53. http://dx.doi.org/10.1002/tl.443.

Wolters. C.A. (1998). Self-Regulaed Learning and College Students'Regulaion of Motivation. Journal of Educational Psychology, 90 (2), 224-235.

Zimmerman, B. J. (1989). Developing self-fullfilling cycles of academic regulation: An analysis of exemplary instructional models. In D. H. Schunk \& B. J. Zimmerman (Eds.), Selfregulated learning: From teaching to self-reflective practice (pp. 1-19). New York, NY: Guilford Press.

Zimmerman, B. J. (2012). Goal setting: A key proactive source of academic self-regulation. In Schunk, D.H. \& Zimmerman, B.J. (Eds.), Motivation and Self-Regulated Learning Theory, Research, and Applications (pp.267 295). New York, NY: Routledge Taylor \& Francis Group. 